画像診断と機能検査

閉塞型睡眠時無呼吸症候群

札幌医科大学耳鼻咽喉科学教室

朝 倉 光 司, 形 浦 昭 克
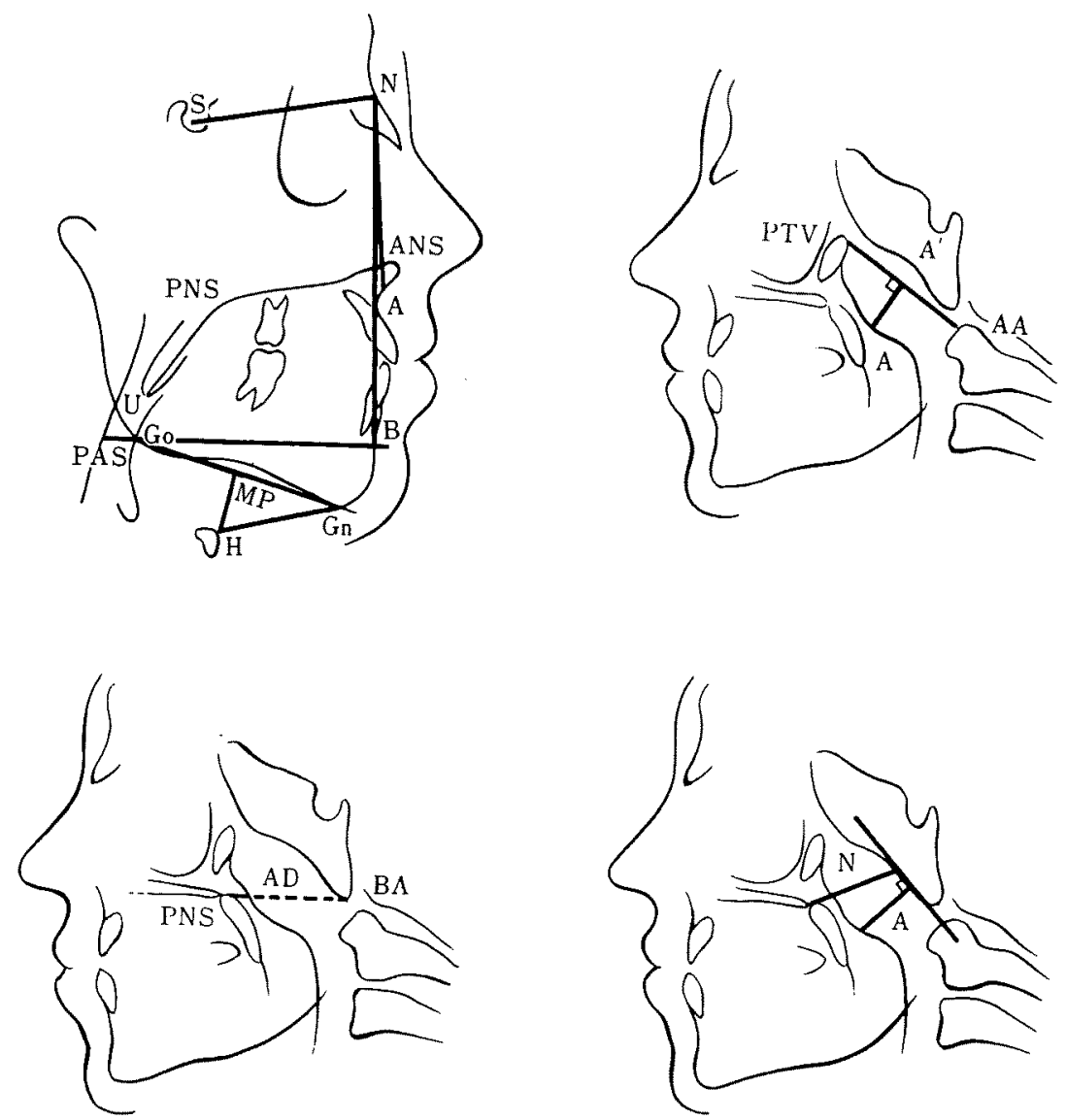

図 1 顔面側面単純 XP 解析のパラメーター

左上：顔面頭蓋骨の計測

(角度パラメーター; SNA, SNB, GoGnH, 距離パラ

メーター; PNS-U, PAS, MP-H)

左下：上咽頭内腔の計測 (PNS-A)

右上：アデノイドの計測 $\left(\mathrm{AA}^{\prime}\right)$

右下：アデノイドの計測 ( $\mathrm{A} / \mathrm{N}$ 比)

\section{1. 画像診断}

閉塞型睡眠時無呼吸の画像診断の目的は，上気道狭窄 の原因部位および程度の診断である。狭窄の原因は，上 気道内の軟部組織によるものと頭蓋骨顔面形態異常によ るものが挙げられる。これらの評価は主に顔面側面単純 XPやCT, MRIを用いて行われる.

\section{1) XP 画像}

顔面側面 XP による計測 (Cephalometric analysis)て は, 数多くの計測点とパラメーターが用いられるが,オー ソドックスなものとして以下のようなものが挙げられる (図 1 ). 
表 1 成人閉塞型無呼吸患者の顔面頭蓋骨計測值

\begin{tabular}{c|c|c|c|c|c|c}
\hline AHI & $\mathrm{n}$ & SNA & SNB & PNS-U & PAS & MP-H \\
\hline $0 \sim 9.9$ & 25 & $85.0 \pm 1.0$ & $81.5 \pm 0.8$ & $48.5 \pm 1.0$ & $13.5 \pm 0.8$ & $20.9 \pm 1.5$ \\
$10 \sim 29.9$ & 15 & $84.6 \pm 1.2$ & $80.2 \pm 1.1$ & $49.8 \pm 2.3$ & $11.1 \pm 1.0$ & $24.9 \pm 2.0$ \\
$30 \sim 49.9$ & 18 & $80.8 \pm 0.9^{* *}$ & $77.5 \pm 1.1^{* *}$ & $50.8 \pm 1.5$ & $10.4 \pm 0.8$ & $28.6 \pm 1.7^{* *}$ \\
$50 \sim$ & 12 & $81.5 \pm 1.2^{*}$ & $77.8 \pm 1.2^{*}$ & $56.1 \pm 2.4^{*}$ & $13.9 \pm 1.2$ & $30.5 \pm 2.1^{* *}$ \\
\hline
\end{tabular}

AHI : apnea-hypopnea index, BMI : body mass index

$*: \mathrm{p}<0.05, * *: \mathrm{p}<0.01$, each value represents mean \pm SEM

SNA (角度) は，上顎の突出度 (発育) の程度を示し， これが小さい人では上咽頭腔や軟口蓋・咽頭後壁間陵が 狭くなる. SNB (角度) は, 下顎の突出度 (発達の程度) を示し，これが小さい人では舌が比較的後方に押しやら れるために舌根での狭䆣が生じやすい. PAS (長さ) は, 舌根での気道の奥行きを示す. PNS-U (長さ) は, 軟口 蓋・口蓋垂の長さを反映する，MP-H（長さ）と GoGnH (角度)は, 舌骨の位置を示し,これらが大きい程舌骨が 下方に位置していることになる，なお，重症な患者では 舌骨が下方に偏位していることが多い。なお，これらの 計測值は，重症な患者ほど異常值を示す頻度が多くなる
(表 1).

小児ではアデノイドや口蓋扁桃の肥大が気道狭窄の大 きな原因となっているため, 側面 XPによるアデノイド 肥大の評価が重要である.アデノイド計測のパラメー ターとしては， $\mathrm{AA}^{\prime}$ (翼突窩最上点 PTV と舞椎前縁 $\mathrm{AA}$ を結ぶ直線とアデノイド最先端の垂直距離，小泉の計 測), $\mathrm{A} / \mathrm{N}$ 比(後頭骨の直線部分から最も突出したアデ) イドの頂点までの直線距離 $\mathrm{A}$ と蝶形骨・後頭骨縫合の前 下端から PNS までの直線距離 $\mathrm{N}$ との比)があり, 上咽頭 内腔の計測には, PNS-A（後鼻棘 PNS と基底点 BA を 結ぶ直線距離のうちの気道部分) を用いる。

専門講座の合本を刊行中です．合本II（昭和53年〜 57年）は 1 冊につき 2,500 円，III（昭和58～62年）は3,000円， IV（昭和63〜平成 4 年）は2,000円です。ご希望の方は現金書留または郵便振替（00130-8-17620）にてお申し込み 下さい. T108 東京都港区高輪3-23-14-807 社日本耳鼻咽喉科学会 

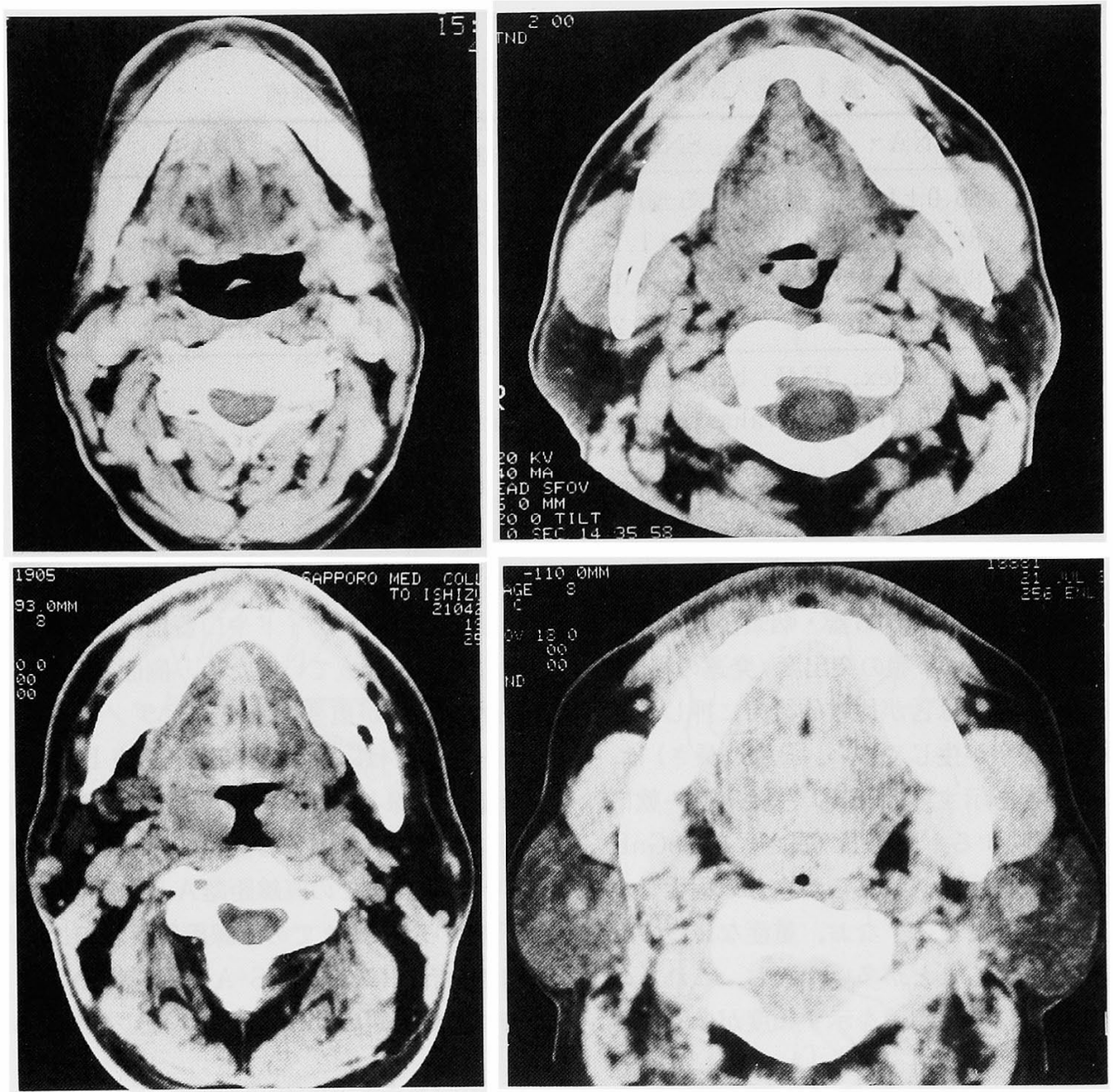

図 2 CT 画像所見（中咽頭レベル） 左上: 正常者 左下: 成人無呼吸患者（扁桃肥大を認める） 右上: 成人無呼吸患者（咽頭腔が全体に狭く, 口蓋垂が狭窄を助長している） 右下：成人無呼吸患者（著明な咽頭腔の狭窄を認める）

表 2 CT による成人の咽頭腔相対面積計測結果

\begin{tabular}{l|c|l|l|c}
\hline & $\mathrm{n}$ & \multicolumn{1}{|c|}{ 上咽頭 } & \multicolumn{1}{|c|}{ 中咽頭 } & 舌根・下咽頭 \\
\hline 対照群 & 6 & $1.38 \pm 0.49$ & $1.87 \pm 0.57$ & $2.54 \pm 1.59$ \\
OSAS 患者 & 20 & $0.58 \pm 0.33^{* *}$ & $0.81 \pm 0.61^{* *}$ & $0.91 \pm 0.49^{*}$ \\
\hline
\end{tabular}

2) CT 画像

CT の水平断を用いると, 上気道の断面積を直接的に 計測することができる，気道の内腔の広さ，軟部組織の 情報, 気道の狭窄部位と程度を知るには単純 XPよりも 直接的でわかりやすい(図 2, 表 2).ただし, 気道の骨 性外枠の情報はXP の方が評価しやすい. 基本的には上 咽頭, 中咽頭(軟口蓋), 舌根のレベルの 3 部位での評価 を行うのがよい.
3）UPPP の治療効果と画像解析の関係

成人の閉塞型睡眠時無呼吸患者では, UPPP (口蓋垂軟 口蓋咽頭形成術）が行われる。その治療効果と術前の画 像解析との関連を調べた結果, 非改善群では XP 上の計 測で下顎が小さく (SNB), 舌骨が下方に位置しており (MP-H, GoGnH), CT 画像で舌根レベルでの気道狭窄 が著しい. 


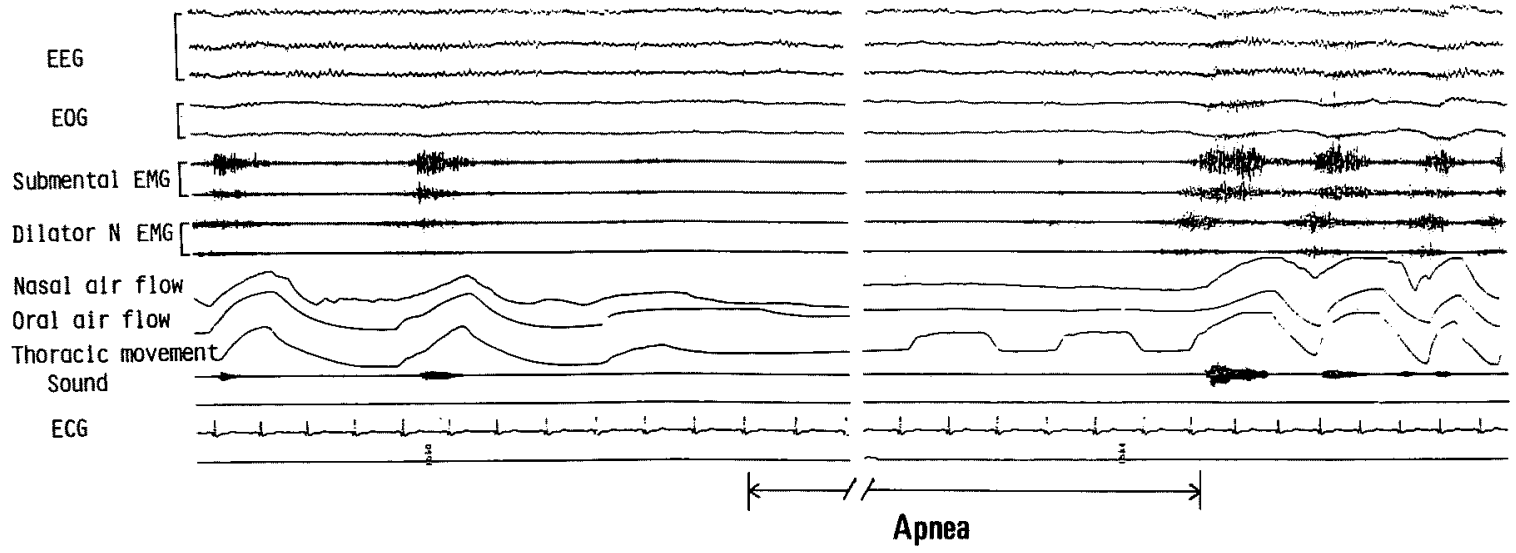

図 3 閉塞型睡眠時無呼吸患者のポリグラフ所見 鼻と口の気流の停止（無呼吸）を認めるが，胸郭の呼吸性運動は継続している。 無呼吸に一致して呼吸補助筋の筋活動の低下，いびき音の消失を認める.

\section{2、睡眠時ポリグラフ}

睡眠時無呼吸症候群の診断のためのポリグラムは，1) 鼻およびロからの気流のモニター，2）胸郭の呼吸性運 動のモニター，3）睡眠ステージ診断のための脳波抢よ び眼球運動のモニターが最低限必要な構成成分である. 気流の停止すなわち無呼吸の際の胸郭運動（呼吸性の活 動)の状態によって無呼吸の分類がなされる，すなわち， 閉塞型では無呼吸の際にも胸郭の呼吸性運動は継続して おり，中枢型では胸郭運動も同時に停止する。また，混 合型では気流も胸郭運動も同時に停止する点は中枢型に 似ているが, 気流の呼吸性の変動の再開より前に胸郭運 動が徐々に開始するもので，これは閉塞型無呼吸の亜型 と考えられている.睡眠時ポリグラフにはささらに 4) 呼 吸補助筋筋電図，5）心電図，6）食道扝よび気道内圧モ ニター，7）経皮的動脈血酸素飽和度 $\mathrm{SpO} 2 ， 8 ）$ いびき 音，9）ビデオモニター等が目的に応じて組み込まれる (図 3 )。食道内压の測定は, 気道閉塞の程度を反映する
が，複数の圧センサーを(上,) 中，下咽頭にあらかじめ 設置して扔くと，気道閉塞の部位診断が可能である. $\mathrm{SpO} 2$ の測定は無呼吸の程度を評価するのに有用であ る。また心電図は無呼吸の際の不整脈の発生の有無を知 ることが出来る．睡眠時ポリグラフ測定は，通常，シー ルドルームを必要とし，電極の不良等に備えて誰かが泊 まり込む必要がある．また，測定デー夕の解析にも手間 がかかる. 欧米のようにパラメディカルが24時間態勢で 詰めている睡眠センター的な施設の少ない日本の現状で は，医療者側の負担が大きいのが欠点である。

なお最近は種々の簡易モニターが開発されており，無 呼吸の診断が比較的容易にできるようになってきてい る.

\section{参考文献}

朝倉光司：画像診断，特集，睡眠時呼吸障害といびき. JHONS 7: 893-898, 1991 